\title{
Finite Element Study of Container Structure under Normal and High Temperature
}

\author{
Xiaoxiong Zha and Yang Zuo \\ School of Civil and Environment Engineering, Harbin Institute of Technology Shenzhen Graduate School, Shenzhen 518055, China \\ Correspondence should be addressed to Xiaoxiong Zha; zhaxx@hit.edu.cn
}

Received 13 September 2015; Revised 11 December 2015; Accepted 15 December 2015

Academic Editor: Francesco Franco

Copyright ( 2016 X. Zha and Y. Zuo. This is an open access article distributed under the Creative Commons Attribution License, which permits unrestricted use, distribution, and reproduction in any medium, provided the original work is properly cited.

\begin{abstract}
This paper does some research on the mechanical property of multilayer container structure under high temperature and gives some suggestions on how to make fire protection based on the performance-based fire design. Firstly, using the software of FDS (Fire Dynamics Simulator), the fire background and fire heating release curve are determined. Through the simulation, the actual temperature curves (of the top and bottom temperature curves of the middle, door, and corner position in the container) are obtained and compared with the standard temperature curve of ISO-834. Secondly, using the software of Abaqus, a full scale finite element model of multilayer container structure is established. Two temperature fields under the standard temperature curve of ISO-834 and the actual temperature curve (of the most unfavorable curve of the top temperature curve of the middle position in the container) are obtained, respectively. Thirdly, the thermal-mechanical coupled analysis is carried out for the container structure under the wind loading and temperature field. The research result can be feasible in design and construction of container buildings and provides some references to corresponding specification preparation.
\end{abstract}

\section{Introduction}

As a light steel structure, containers are increasingly used for building structures as shown in Figure 1. Container buildings have many advantages and applications. Firstly, container steel is recyclable and thus reduces energy consumption and environmental pollution. Secondly, containers are normally manufactured in factory, transported to and quickly assembled at construction sites, which follows a standardized design and construction process that is easy to manage and construct. Thirdly, containers can be in a variety of forms depending on architectural design requirements. Due to the above advantages, containers are used not only for general residential buildings, but also for public buildings, disaster relief housings, fields, and military constructions [1].

In architectural aspects of container buildings, Kotnik [1] introduced the top container building projects around the world, including many recent cases which got domestic and foreign awards. Through extensive real map, vertical and plan view, each project was shown. Slawik et al. [2] described the developmental background and evolution of the container buildings and cited many examples which illustrated the important role of container buildings in today's urban and rural areas. More important, a variety of combinations of container buildings, standards, as well as costs, were given. Sawyers [3] commented on manufacture process of container buildings and introduced foundation, connection, doors, windows, interior decoration, and other specific construction processes based on some project examples. Gordon et al. [4], through a large number of engineering examples and pictures, described construction process of container buildings as well as interior decoration. Smith [5] introduced British housing problems and container building background information, what is more, described container building insulation issues, and drew many useful conclusions.

Though, as a special form of buildings, containers have been widely accepted by the construction industry, there are still demands from the design community for further study on their structural performance. In structural aspects of container buildings, Suzuki [6-9] used finite element method 


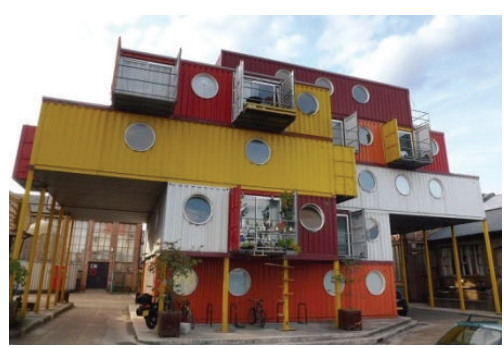

(a) The Container City of London

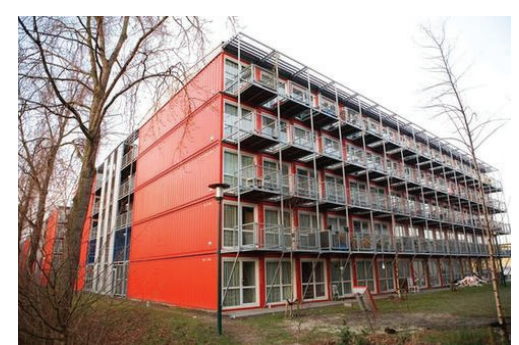

(b) The dormitory of Amsterdam

FIGURE 1: The container building.

to analyze vibration of stacked containers. The numerical model was validated by full-size tests. However, the majority of research was focused on dynamics of container stacking in maritime transport. Børvik [10, 11] used aluminum board to design envelope structures and then used finite element method to simulate mechanical properties of the protective structures under impact of explosion. Finally, a full-size container with protective structure was tested to verify the finite element analysis. In these studies, the interactions between the side walls and the frame of container and the integrated container stiffness were not considered. Harrison [12] described antiknock performance of blast resistant portable buildings (BRPBs) and presented different applications that was installed at various facilities. But, the mechanical properties of boundary condition and corrugated sheet were lacked. Sinha et al. [13] proposed a space frame model for calculating stresses and deflections of containers subjected to some loading conditions when compared with experimental results. It was found that the side wall simulations provided unsatisfactory results, probably because modeling a container as a space frame for lifting and restraint tests did not represent a good simulation of the actual test conditions. Giriunas [14, 15] introduced relevant container standards and foundation, connection, reinforcement of container buildings, and developed finite element models to predict stiffness of a variety of container structures under various loading conditions. However, the corresponding experimental verification was lacked. Zha $[16,17]$ proposed a container optimal model and has taken the lightest total weight as the objective function and the strength and stiffness are taken as the constraint conditions. The optimal cross-sectional size of beam and column was obtained. Zuo and Zha [18] used diaphragm theory to give a mechanical analysis and stiffness calculation method of container with holes and then used Abaqus to give the influence law of parameters on the stiffness of container with holes. Finally, five experimental studies of container with holes were verified. Zha $[19,20]$ proposed the formula of container stiffness as the single layer and multispan, multilayer and single-span, and multilayer and multispan based on the principle of displacement coordination and diaphragm theory and then proposed a new isolation system based on friction energy between containers, and the relationship between equivalent damping ratio and friction coefficient of sliding isolation structure had been gotten.
This paper presents a study on the mechanical properties of container structure under high temperature. Based on the performance-based fire design, the thermal-mechanical coupled analysis of container buildings is given.

\section{The Fire Simulation in Container}

2.1. The Design of Fire Scene. The setting of fire scene is an important step of performance-based fire design and fire risk assessment and mainly includes the following two aspects. The first aspect is to determine the fire background, which includes the building structure, the distribution of combustible materials, and the ventilation conditions. The second aspect is to determine the fire heating release curve, which describes the occurrence, growth, development, and extinction of the fire [21].

2.1.1. The Determination of Fire Background. The overall space size of the FDS model is established according to the actual size of the container. In the two ends of the container, the door of $1 \mathrm{~m} \times 2 \mathrm{~m}$ and the window of $1 \mathrm{~m} \times 1 \mathrm{~m}$ are set to simulate the outdoor environment, and the condition of ventilation is good. The side walls of the container are set as adiabatic walls, and the mechanical ventilation is not considered. The air temperature before the fire takes is $20^{\circ} \mathrm{C}$. In the middle, door, and corner position of the container, the thermocouple devices are set, respectively, to measure the temperature of the corresponding part. The fire source is set as the center position of the room bottom, and the area the fire source takes is $1 \mathrm{~m} \times 3 \mathrm{~m}$ as shown in Figure 2 .

According to the literature of "Fire Engineering Guider of Australia," the heating power of fire and the calorific value the combustible materials take are $0.466 \mathrm{MW} / \mathrm{m}^{2}$ and $560 \mathrm{MJ} / \mathrm{m}^{2}$, respectively, in unit area as the fire scene in container is more close to the office.

Based on the above data, the maximum heating release speed the fire source takes is $0.466 \times 3 \times 1=1.398 \mathrm{MW}$, and the calorific value the combustible materials take is $560 \times 3 \times 1=$ $1680 \mathrm{MJ}$.

2.1.2. The Determination of Fire Heating Release Curve. The determination of fire heating release curve is the core of fire 
scene, and, in this paper, it takes $t^{2}$ model which can be expressed as

$$
Q= \begin{cases}b t^{2} & 0 \leq t<t_{1} \\ Q_{\max } & t_{1} \leq t<t_{2} \\ \frac{Q_{\max }\left(t-t_{3}\right)}{\left(t_{2}-t_{3}\right)} & t_{2} \leq t \leq t_{3} .\end{cases}
$$

According to the classification of NFPA (National Fire Protection Association) in America, the fire developing speed was taken as medium speed. And then, the developing coefficient of fire and the time of heating release speed of $1 \mathrm{MW}$ were taken as $0.0117 \mathrm{~kW} / \mathrm{s}^{2}$ and $292 \mathrm{~s}$, respectively.

According to the literature [22], the heating and stable part should be calculated in the fire analysis, and the falling part can be ignored. So based on (1) and the corresponding fire heating release curve of Figure 3, the fire time of heating part can be calculated as

$$
t_{1}=\sqrt{\frac{1.398 \times 1000}{0.0117}}=345.67 \mathrm{~s} .
$$

And then, the calorific value of combustible materials in the heating part can be calculated as

$$
\int_{0}^{t_{1}} b t^{2} d t=\int_{0}^{345.67} \frac{0.0117}{1000} t^{2} d t=161.08 \mathrm{MJ} .
$$

According to the literature [22], the calorific value of combustible materials in the heating and stable part is about $70 \%$ of the total calorific value. And then, the calorific value of combustible materials in the stable part can be calculated as

$$
1680 \times 70 \%-161.08=1014.92 \mathrm{MJ} .
$$

And then, $t_{2}$ can be calculated as

$$
t_{2}=345.67+\frac{1014.92}{1.398}=1071.65 \mathrm{~s} .
$$

So the whole fire time is about $1072 \mathrm{~s}$ based on the above analysis.

2.2. The Grid Division of the FDS Model. The grid division is the basis of FDS model calculation, and the grid division is more fine and the calculation result is more accurate, but the calculation time is also longer. In the grid division of FDS model, the method of the ratio between the diameter of equivalent fire source and the grid size can be used based on the literature [21]. When the ratio is $4 \sim 16$, the relatively accurate result can be get. The diameter of equivalent fire source can be expressed as

$$
D^{*}=\left(\frac{Q}{\rho_{a} c_{P} T \sqrt{g}}\right)^{2 / 5} .
$$

$g, c_{P}$, and $\rho_{a}$ can be taken as $9.8 \mathrm{~m} / \mathrm{s}^{2}, 1.005 \mathrm{~kJ} /(\mathrm{kgK})$, and $1.204 \mathrm{~kg} / \mathrm{m}^{3}$, respectively. Through (6), the grid size should be $0.19 \mathrm{~m} \sim 0.8 \mathrm{~m}$. In order to meet the requirements of FDS for grid size and quantity, the grid size is taken as $0.21 \mathrm{~m} \times 0.19 \mathrm{~m}$ $\times 0.19 \mathrm{~m}$ in this paper.

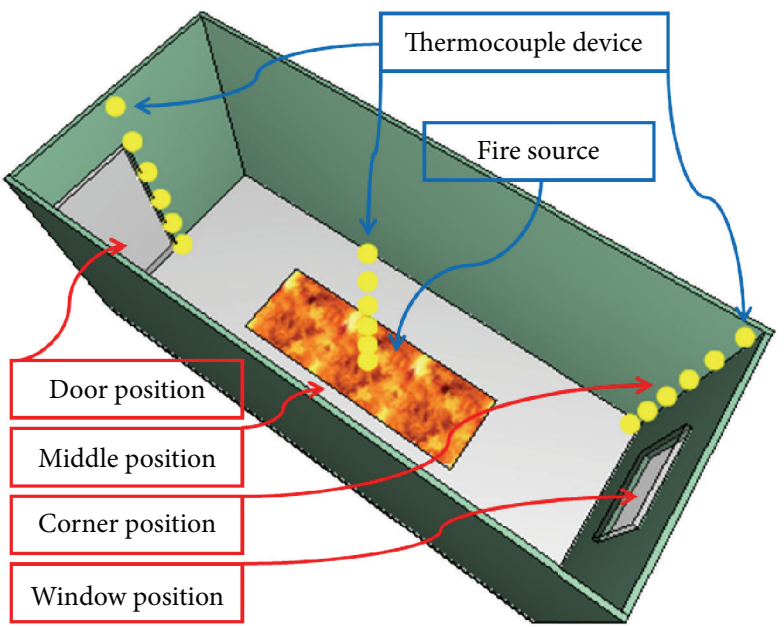

FIGURE 2: The FDS model of container.

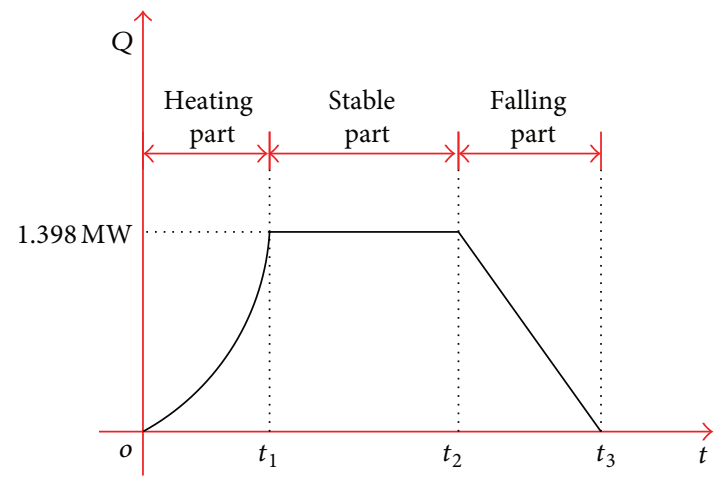

FIGURE 3: The fire heating release curve.

2.3. The Results and Analyses of the FDS Simulation. According to the setting position of thermocouple devices as shown in Figure 2, the actual temperature curve (the top and bottom temperature curves of the middle, door, and corner position in the container) and the corresponding standard temperature curve of ISO-834 [23] are as shown in Figures 4,5 , and 6 , respectively.

The following conclusions can be obtained from Figures 4,5 , and 6 .

(1) When the container is in fire, there is a large difference in temperature between the bottom and top of the container, and the temperature increases gradually from the bottom to the top. The reason is that the hot air is lighter than the cold, and it concentrates in the top of the container firstly and then develops to the bottom with time.

(2) The upper temperature of fire source is higher than the other parts of the container. The reason is that the upper temperature of fire source is affected not only by the hot air, but also by the heating radiation. However, the temperature of other parts in the container is mainly affected by the hot air flow. 


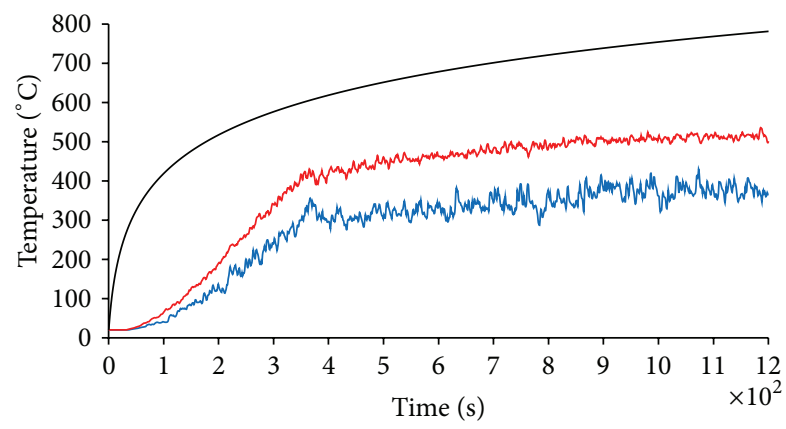

— The standard temperature curve of ISO-834

The top temperature curve

_ The bottom temperature curve

FIgURE 4: The top and bottom temperature curves of the middle position in the container.

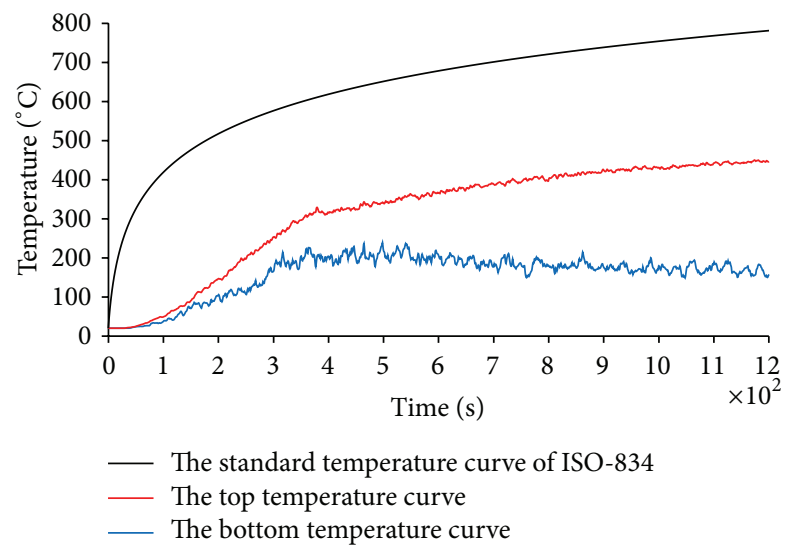

Figure 5: The top and bottom temperature curves of the door position in the container.

(3) There is a relatively large difference between the actual temperature curve (the top and bottom temperature curves of the middle, door, and corner position in the container) and the standard temperature curve of ISO-834, which shows the importance and necessity of the study on the actual temperature curve and shows the science of the study on the performancebased fire design.

\section{The Temperature Field Analysis in Container}

\subsection{The Overview of Container Structure}

3.1.1. The Structure of Container. The main members and size of container as shown in Figure 20, and more extensive information of container can refer to the relevant literature [24].

3.1.2. The Boundary Conditions of Container. A six-layer container structure is fixed on the ground through the bottom side beams and corner fittings, and each layer is fixed through

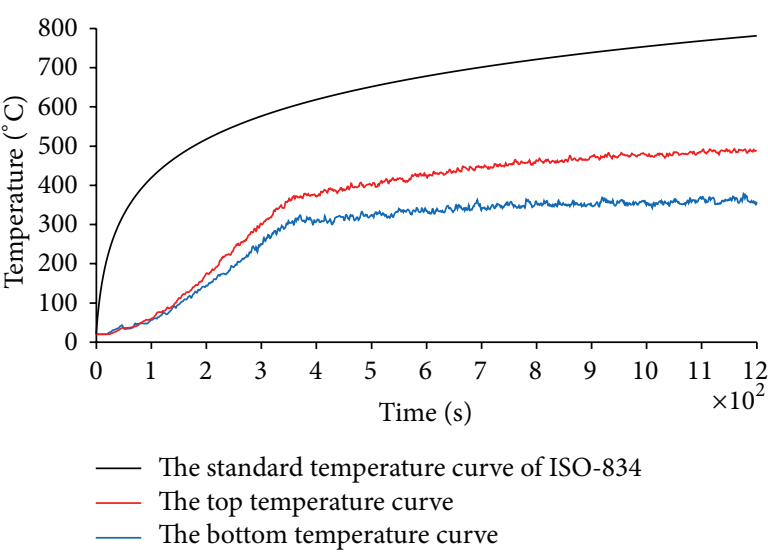

FIGURE 6: The top and bottom temperature curves of the corner position in the container.

the top and bottom corner fittings as shown in Figures 7(b) and $7(\mathrm{c})$.

The container structure bears wind loading, and the lateral and longitudinal equivalent wind loading of the top corner fittings of each layer is shown in Figure 7(b), and the corresponding value of wind loading based on the literature [25] is shown in Table 1.

\subsection{The Container Finite Element Model}

3.2.1. The Establishment of Container Model. The nonlinear finite element software Abaqus [26-28] is used as primary means of finite element analysis. The material parameters and constitutive relationship of container model are based on the material experiment [29] as shown in Table 2 and Figure 8. The density of container steel is taken as $\rho=7850 \mathrm{~kg} / \mathrm{m}^{3}$.

For the element size, shape, technique, and type of each container members are as shown in Tables 3 and 4.

Through the above analysis, the container finite element model is as shown in Figure 9.

3.2.2. The Parameters of Temperature Field Analysis. In the temperature field analysis of six-layer container structure, the corresponding material parameters of container steel are as follows.

(1) The Density of Steel. The density of steel is not affected by temperature obviously and can be assumed that it is taken as $\rho=7850 \mathrm{~kg} / \mathrm{m}^{3}$.

(2) The Poisson Ratio of Steel. The Poisson ratio of steel is not affected by temperature obviously, and it can be assumed that it is taken as in Table 2.

(3) The Thermal Expansion Coefficient of Steel. According to the literature [23], the thermal expansion coefficient of steel is taken as $\alpha_{s}=1.4 \times 10^{-5} \mathrm{~m} /\left(\mathrm{m}^{\circ} \mathrm{C}\right)$. 
(4) The Thermal Conduction Coefficient of Steel. According to the literature [23], the thermal conduction coefficient of steel can be expressed as

$$
\lambda_{s}= \begin{cases}54-3.33 \times 10^{-2} \mathrm{~T} & 20^{\circ} \mathrm{C} \leq \mathrm{T}<800^{\circ} \mathrm{C} \\ 27.3 & T \geq 800^{\circ} \mathrm{C} .\end{cases}
$$

(5) The Specific Heat of Steel. According to the literature [23], the specific heat of steel can be expressed as

$$
C_{s}= \begin{cases}425+7.73 \times 10^{-1} T-1.69 \times 10^{-3} T^{2}+2.22 \times 10^{-6} T^{3} & 20^{\circ} \mathrm{C} \leq T \leq 600^{\circ} \mathrm{C} \\ 666+\frac{13002}{(738-T)} & 600^{\circ} \mathrm{C} \leq T \leq 745^{\circ} \mathrm{C} \\ 545+\frac{17820}{(T-731)} & 745^{\circ} \mathrm{C} \leq T<900^{\circ} \mathrm{C} \\ 650 & 900^{\circ} \mathrm{C} \leq T<1200^{\circ} \mathrm{C} .\end{cases}
$$

(6) The Elastic Modulus and Yield Stress of Steel. According to the literature [23], the elastic modulus and yield stress of steel can be expressed as

$$
\begin{aligned}
& \chi_{T}=\frac{E_{T}}{E}= \begin{cases}\frac{7 T-4780}{6 T-4760} & 20^{\circ} \mathrm{C} \leq T<600^{\circ} \mathrm{C} \\
\frac{1000-T}{6 T-2800} & 600^{\circ} \mathrm{C} \leq T<800^{\circ} \mathrm{C},\end{cases} \\
& \eta_{T}=\frac{f_{y T}}{\sigma_{s}}= \begin{cases}1.0 & 20^{\circ} \mathrm{C} \leq T<300^{\circ} \mathrm{C} \\
1.24 \times 10^{-8} T^{3}-2.096 \times 10^{-5} T^{2}+9.288 \times 10^{-3} T-0.2168 & 300^{\circ} \mathrm{C} \leq T<800^{\circ} \mathrm{C} \\
0.5-\frac{T}{2000} & 800^{\circ} \mathrm{C} \leq T<1000^{\circ} \mathrm{C} .\end{cases}
\end{aligned}
$$

(7) The Coefficient of Convective Heat Transfer. According to the literature [23], the coefficient of convective heat transfer is as shown in Table 5.

\subsubsection{The Temperature Curves for Temperature Field Analysis.} In order to compare the prescriptive fire design and the performance-based fire design, two temperature curves of the standard temperature curve of ISO-834 and the actual temperature curve have been selected to calculate the temperature field as shown in Figure 10. On the conservative side, the actual temperature curve is taken as the most unfavorable curve of the top temperature curve of the middle position in the container. According to (5), the whole fire time is taken as $1200 \mathrm{~s}$.

3.3. The Results and Analyses of Temperature Field. The steel frame as an important structure of bearing loading must be set as the fire protection. For the container structure, the side wall has the important effect on the mechanical properties of the container structure and should be protected against the fire. However, the cost will be very great on the condition of setting fire protection to the side wall. So this part is mainly for the study on temperature field analysis in container on the condition of the beams and columns with the fire protection and the side wall without fire protection. For the multilayer container structure, the most dangerous situation is the fire in the bottom layer, so the analysis of this part is setting the fire at the bottom of container structure.

Based on Figure 10 of two temperature curves (the standard temperature curve of ISO-834 and the actual temperature curve), the corresponding two temperature fields can be obtained, respectively, as shown in Figures 11 and 12 according to the transient thermal analysis. The temperature fields of bottom layer in container structure are given as the fire only in the bottom layer. As the container roof of the bottom layer is totally connected to the container bottom of the second layer which is made of concrete, the container roof of the bottom layer maintains the initial temperature.

The following conclusions can be obtained from Figures 11 and 12 .

(1) At the same time, the temperature value of temperature field under the standard temperature curve is obviously higher than under the actual temperature curve. The reason is that the performance-based fire design considers more factors which affect the structural temperature in the fire. But if prescriptive fire design is used, the results will be very conservative and lead to high cost. 


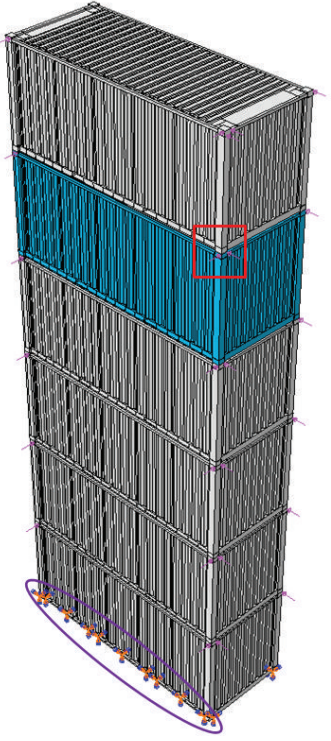

(a) The six-layer container structure

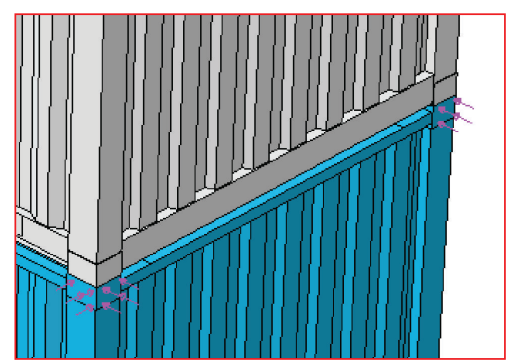

(b) The connection of each layer and the lateral and longitudinal equivalent wind loading

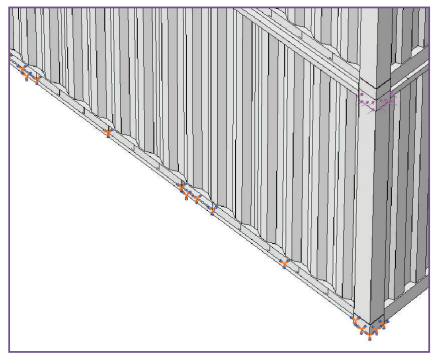

(c) The connection between container structure and ground

FIGURE 7: The boundary conditions of six-layer container structure.

TABLE 1: The lateral and longitudinal equivalent wind loading of the top corner fittings of each layer (N/mm²).

\begin{tabular}{lcccccc}
\hline Layer & 1 & 2 & 3 & 4 & 5 & 6 \\
\hline The lateral equivalent wind loading & 0.729 & 0.729 & 0.729 & 0.736 & 0.785 \\
\hline The longitudinal equivalent wind loading & 0.322 & 0.322 & 0.322 & 0.325 & 0.347 \\
\hline
\end{tabular}

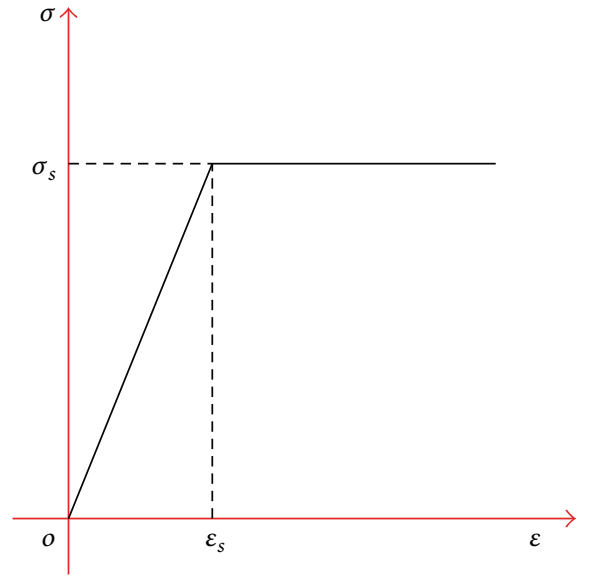

FIGURE 8: The constitutive relationship of container model.

(2) The temperature value of temperature field under the standard temperature curve increases rapidly at the beginning and then increases slowly with time. However, the temperature value of temperature field under the actual temperature curve increases slowly in $0-300 \mathrm{~s}$ and then increases rapidly in 300-600 s
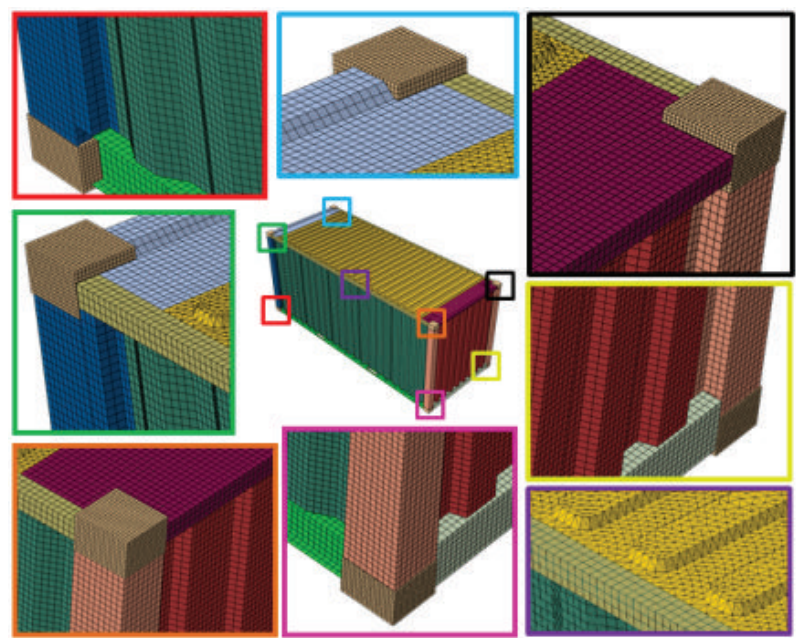

FIgURE 9: The container finite element model.

and then increases slowly again. This is similar to the actual temperature curve.

(3) Although the fire loading is only acting on the side wall, the beam and column have a certain temperature by heat conduction as the side wall, beam, and column 


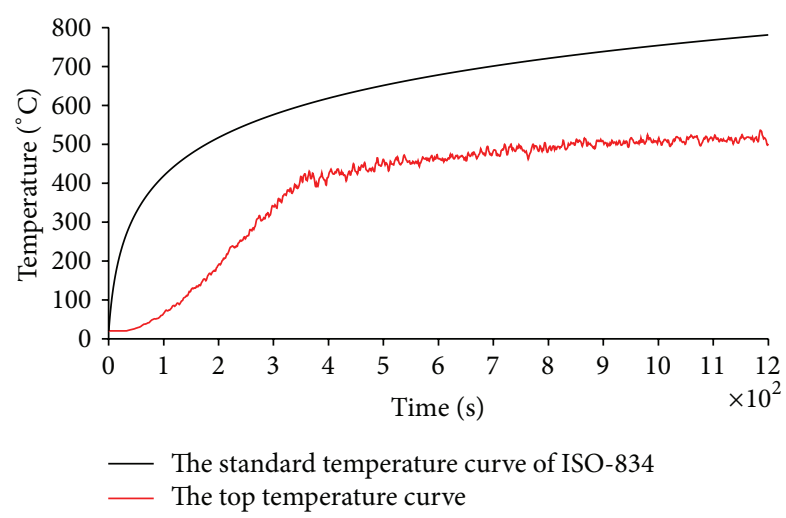

FIGURE 10: The top temperature curves of the middle position in the container.

TABLE 2: The material parameters of container model.

\begin{tabular}{lcccc}
\hline Specimen & $E(\mathrm{MPa})$ & $\mu$ & $\sigma_{s}(\mathrm{MPa})$ & $\sigma_{b}(\mathrm{MPa})$ \\
\hline Corner column & $2.03 \times 105$ & 0.3 & 320.83 & 461.87 \\
U-steel & $2.04 \times 105$ & 0.28 & 325.89 & 476.21 \\
Top side beam & $1.99 \times 105$ & 0.31 & 314.33 & 449.12 \\
Bottom side beam & $2.01 \times 105$ & 0.3 & 318.44 & 458.07 \\
Side wall, 1.6 mm & $1.97 \times 105$ & 0.3 & 318.67 & 448.2 \\
Side wall, $2 \mathrm{~mm}$ & $1.98 \times 105$ & 0.29 & 324.17 & 452.95 \\
\hline
\end{tabular}

are connected by welding. But the temperature is not high.

\section{The Thermal-Mechanical Coupled Analysis for Container}

4.1. The Limit Condition. According to the literature [30,31], the overall damage of the structure in fire is as shown in Figure 13.

The corresponding damage can be judged by the following conditions.

(1) The condition of the column displacement can be expressed as

$$
\frac{\Delta_{h}}{h} \leq \frac{1}{50}
$$

(2) The condition of the beam displacement can be expressed as

$$
\frac{\Delta_{l}}{l} \leq \frac{1}{250}
$$

\subsection{The Structural Analysis under the Standard Temperature Curve}

4.2.1. The Stress Analysis. The stress of the second and above layers in container structure is relatively small as the fire in the bottom layer. The Mises stress contours of the bottom and second layers at $3600 \mathrm{~s}$ under the temperature field (of standard temperature curve) and external loading (of lateral and longitudinal wind loading) are as shown in Figure 14.

From Figure 14, it can be seen that some areas of the top and bottom side beams of the bottom layer reach to the yield. The reason is that the top and bottom side beams of the bottom layer are restricted by the second layer and ground, respectively, and not able to deform freely which will produce great stress in the beam. Meanwhile, the external loading will also produce stress in the beam. However, the cross section of beam and column fails to reach the total yield, and there is no plastic hinge. So the container structure fails to reach the limit condition and is safe.

4.2.2. The Displacement Analysis. The displacement contours of the container structure at $3600 \mathrm{~s}$ under the temperature field (of standard temperature curve) and external loading (of lateral and longitudinal wind loading) are as shown in Figure 15.

The displacement of the top point of corner column and the middle point of bottom side beam in the bottom layer with time under the temperature field (of standard temperature curve) and external loading (of lateral and longitudinal wind loading) is as shown in Figure 16.

From Figures 16(a) and 16(b), the initial displacement value of the top point of corner column is mainly caused by the action of wind loading. With increasing of the time and temperature, the displacement value increases correspondingly. The reason is that the temperature distribution is uneven in the cross section of corner column which leads to the uneven expansion of the corner column. In addition, the change of steel properties with time and the effect of $P-\Delta$ property also lead to the displacement value increase. From the comparison of Figures 16(a) and 16(b), the displacement value has the obvious differences. The reason is that the area and stiffness of longitudinal and lateral container are different.

From Figures 16(c) and 16(d), the displacement value of the middle point of bottom side beam increases gradually with increasing of the time and temperature. The reason is that the constraints of the side wall on the bottom side beam decrease with increasing of the time and temperature.

According to the limit condition, when the displacement of corner column reaches $h / 50=52 \mathrm{~mm}$ and the displacement of bottom side beam reaches $l / 250=24.2 \mathrm{~mm}$, the overall structure reaches the limit condition. According to Figure 16, the maximum displacement of corner column is $7.3 \mathrm{~mm}$ and $105 \mathrm{~mm}$ under longitudinal and lateral wind loading, respectively, and the maximum displacement of bottom beam is $9.5 \mathrm{~mm}$ and $7.7 \mathrm{~mm}$ under longitudinal and lateral wind loading, respectively.

The displacement of corner column under lateral wind loading does not satisfy limit condition. As the limit condition of corner column displacement is $52 \mathrm{~mm}$, the fire resistance time of the container structure is only approximately $1800 \mathrm{~s}$ from Figure 16(b). In general condition, however, the fire resistance time of steel structure is $1 \mathrm{~h} \mathrm{[23].} \mathrm{So,} \mathrm{under} \mathrm{the}$ 


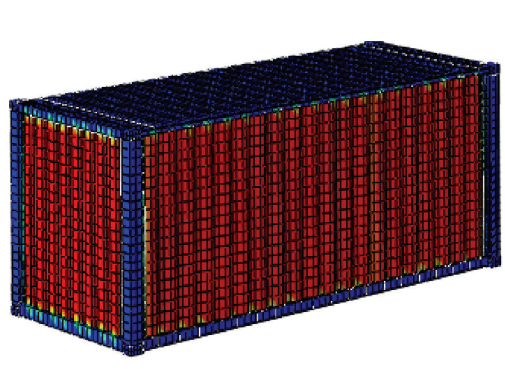

(a) $t=300 \mathrm{~s}$

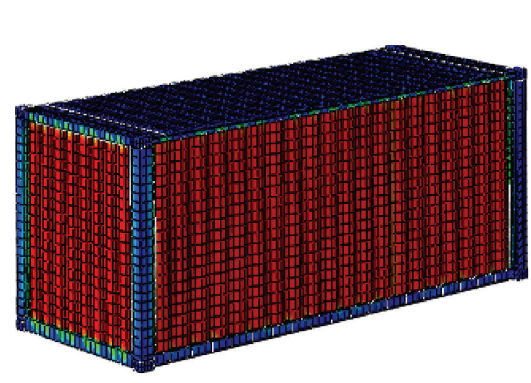

(c) $t=900 \mathrm{~s}$
NT11

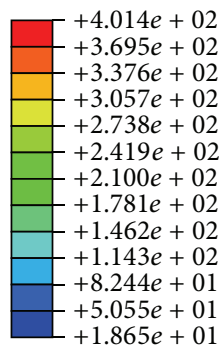

$+5.055 e+01$
$+1.865 e+01$

NT11

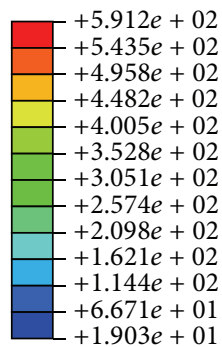

$+1.903 e+0$

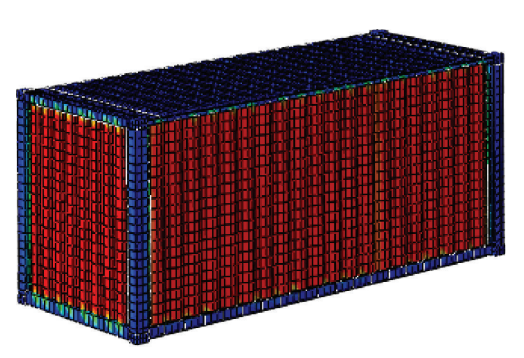

(b) $t=600 \mathrm{~s}$

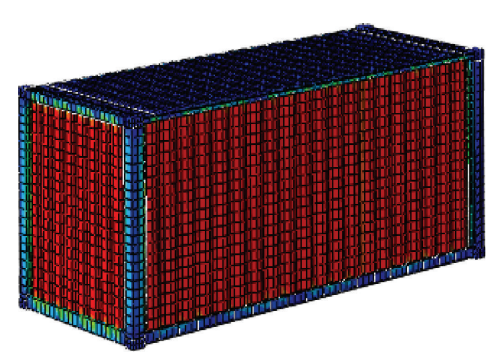

(d) $t=1200 \mathrm{~s}$
NT11

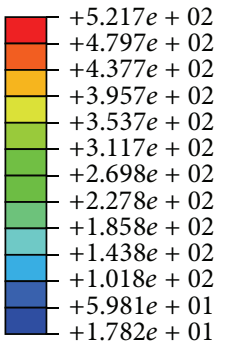

NT11

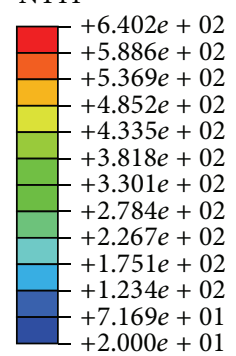

FIGURE 11: The temperature field of the standard temperature curve.

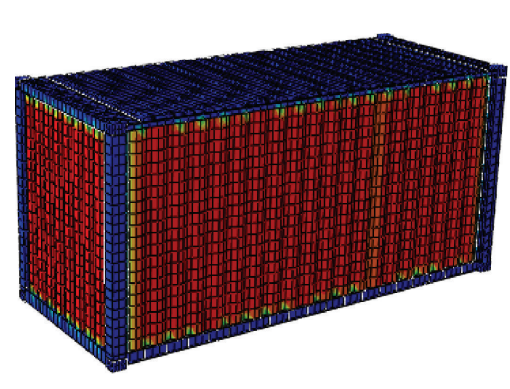

(a) $t=300 \mathrm{~s}$

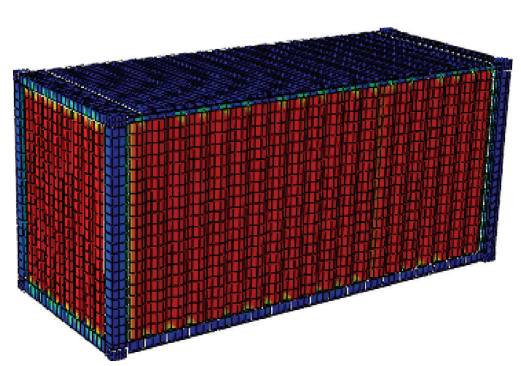

(c) $t=900 \mathrm{~s}$
NT11

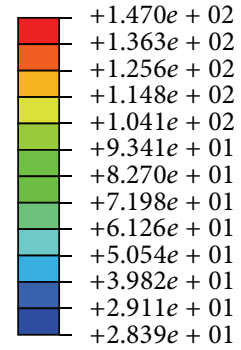

$+2.839 e+01$

NT11

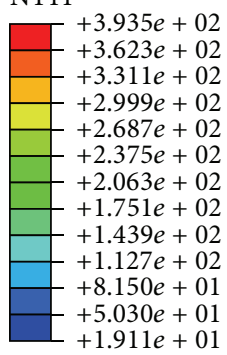

$+5.030 e+01$
$+1.911 e+01$

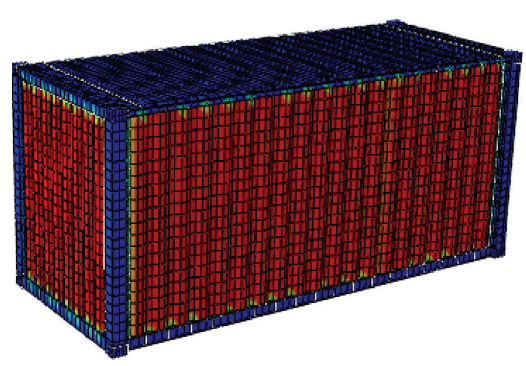

(b) $t=600 \mathrm{~s}$

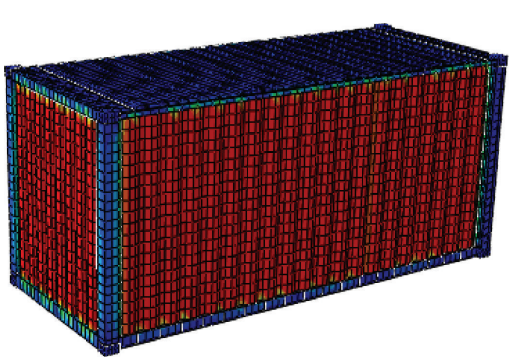

(d) $t=1200 \mathrm{~s}$
NT11

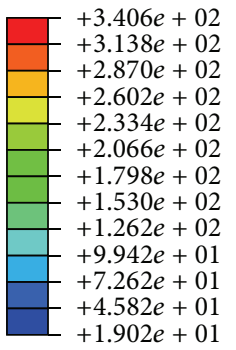

NT11

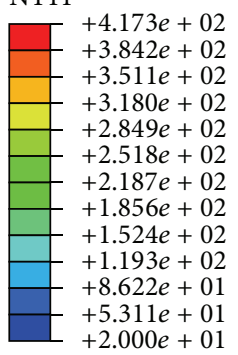

FIGURE 12: The temperature field of the actual temperature curve.

standard temperature curve, the container structure cannot meet the fire resistance requirements on the condition of the bottom side beam and corner column with fire protection only and the side wall without fire protection. Therefore, if the standard temperature curve is used to fire resistance design, not only do the bottom side beam and corner column need fire protection, but also the side wall needs fire protection.

\subsection{The Structural Analysis under the Actual Temperature Curve}

4.3.1. The Stress Analysis. The stress of the second and above layers in container structure is relatively small as the fire in the bottom layer. The Mises stress contours of the bottom and second layers at $1200 \mathrm{~s}$ under the temperature field (of 
TABLE 3: The element of container members, 1.

\begin{tabular}{lcccc}
\hline Name & $\begin{array}{c}\text { Top } \\
\text { side beam }\end{array}$ & $\begin{array}{c}\text { Bottom } \\
\text { side beam }\end{array}$ & $\begin{array}{c}\text { Front } \\
\text { corner column }\end{array}$ & $\begin{array}{c}\text { Rear } \\
\text { corner column }\end{array}$ \\
\hline $\begin{array}{l}\text { Member } \\
\text { form }\end{array}$ & C & & & \\
\end{tabular}

TABLE 4: The element of container members, 2.

\begin{tabular}{|c|c|c|c|c|c|}
\hline Name & $\begin{array}{c}\text { Top } \\
\text { end beam }\end{array}$ & $\begin{array}{l}\text { Bottom } \\
\text { end beam }\end{array}$ & Side wall & Top wall & End wall \\
\hline \multicolumn{6}{|l|}{$\begin{array}{l}\text { Member } \\
\text { form }\end{array}$} \\
\hline $\begin{array}{l}\text { Size } \\
(\mathrm{mm})\end{array}$ & 15 & 15 & 10 & 10 & 10 \\
\hline Shape & Quad & Quad & Quad & Tri & Quad \\
\hline Technique & Structured & Structured & Structured & Free & Structured \\
\hline Type & S4R & S4R & S4R & S3 & S4R \\
\hline
\end{tabular}

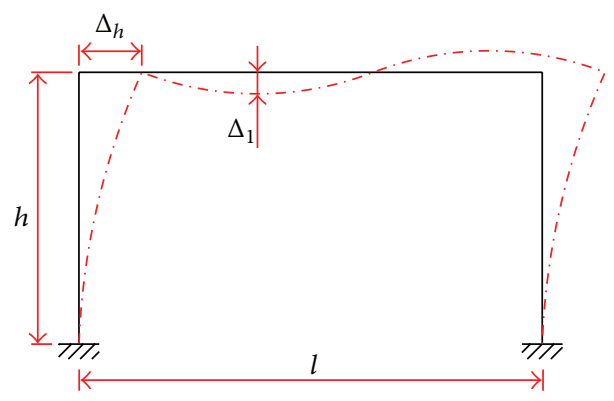

FIGURE 13: The overall damage of the structure in fire.

actual temperature curve) and external loading (of lateral and longitudinal wind loading) are as shown in Figure 17.

From Figure 17, it can be seen that some areas of the top and bottom side beams of the bottom layer reach the yield. The reason is that the top and bottom side beams of the bottom layer are restricted by the second layer and ground, respectively, and not able to deform freely which will produce great stress in the beam. Meanwhile, the external loading will also produce stress in the beam. However, the cross section of beam and column fails to reach the total yield, and there is no plastic hinge. So the container structure fails to reach the limit condition and is safe.
4.3.2. The Displacement Analysis. The displacement contours of the container structure at $1200 \mathrm{~s}$ under the temperature field (of actual temperature curve) and external loading (of lateral and longitudinal wind loading) are as shown in Figure 18.

The displacement of the top point of corner column and the middle point of bottom side beam in the bottom layer with time under the temperature field (of actual temperature curve) and external loading (of lateral and longitudinal wind loading) is as shown in Figure 19.

From Figures 19(a) and 16(b), the initial displacement value of the top point of corner column is mainly caused by the action of wind loading. With increasing of the time and temperature, the displacement value increases correspondingly. The reason is that the temperature distribution is uneven in the cross section of corner column which leads to the uneven expansion of the corner column. In addition, the change of steel properties with time and the effect of $P-\Delta$ property also lead to the displacement value increase. From the comparison of Figures 19(a) and 19(b), the displacement value has the obvious differences. The reason is that the area and stiffness of longitudinal and lateral container are different.

From Figures 19(c) and 19(d), the displacement value of the middle point of bottom side beam increases gradually with increasing of the time and temperature. The reason is 


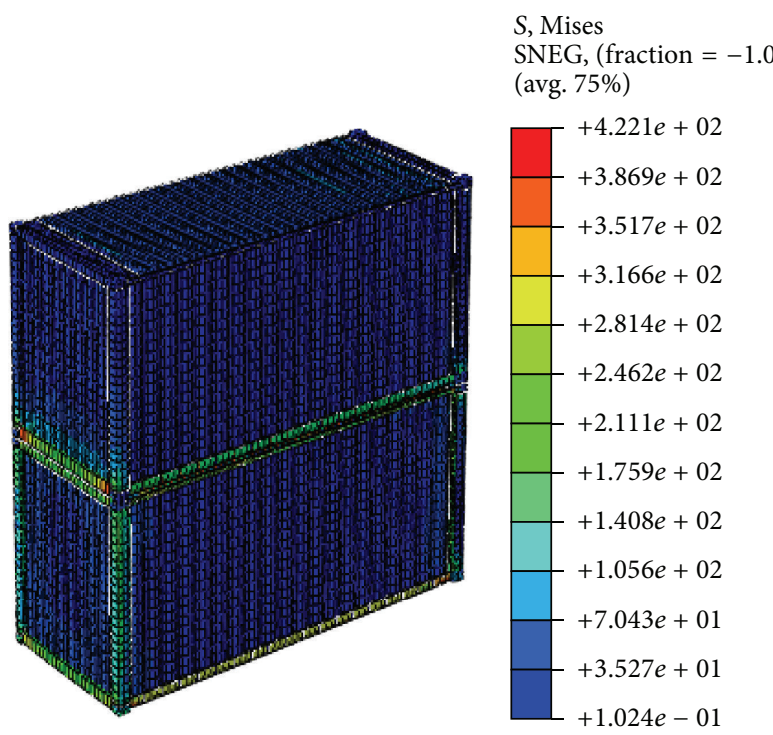

(a) The Mises stress contour under the temperature field and longitudinal wind loading

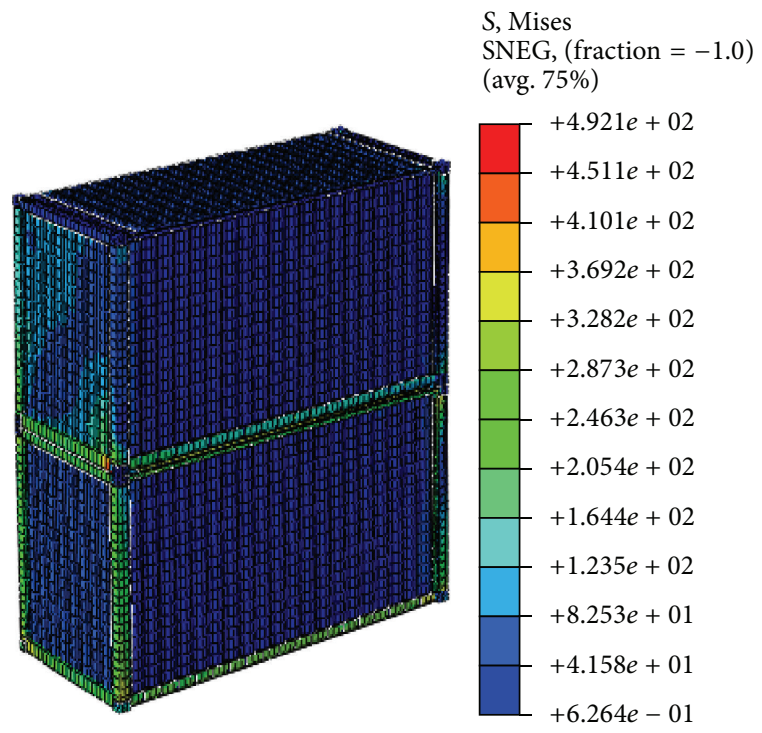

(b) The Mises stress contour under the temperature field and lateral wind loading

Figure 14: The Mises stress contours of the bottom and second layers at $3600 \mathrm{~s}$.

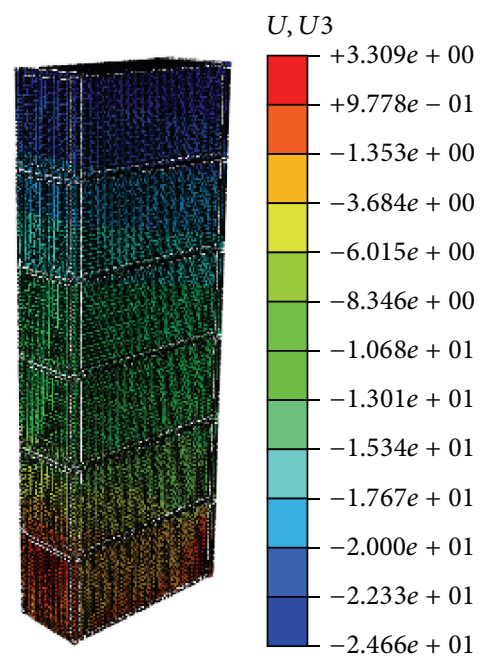

(a) The displacement contour under the temperature field and longitudinal wind loading

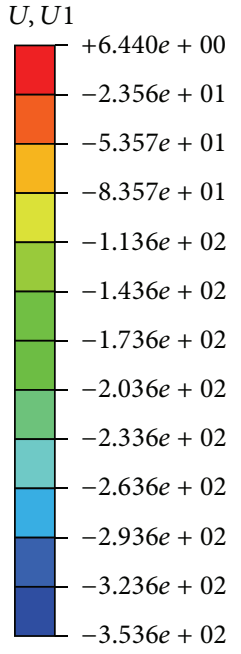

(b) The displacement contour under the temperature field and lateral wind loading

FIgURE 15: The displacement contours of the container structure at $3600 \mathrm{~s}$.

TABLE 5: The coefficient of convective heat transfer.

\begin{tabular}{lcccccccrr}
\hline $\begin{array}{l}\text { Temperature } \\
\left({ }^{\circ} \mathrm{C}\right)\end{array}$ & $60 \sim 200$ & 400 & 500 & 600 & 700 & 800 & 900 & 1000 & 1100 \\
\hline $\begin{array}{l}\text { Coefficient of } \\
\text { convective heat } \\
\text { transfer } \\
\left(\mathrm{W} /\left(\mathrm{m}^{2 \circ} \mathrm{C}\right)\right)\end{array}$ & 11.7 & 17.6 & 23.4 & 35.1 & 46.8 & 64.4 & 81.9 & 105.3 & 140.4 \\
\hline
\end{tabular}




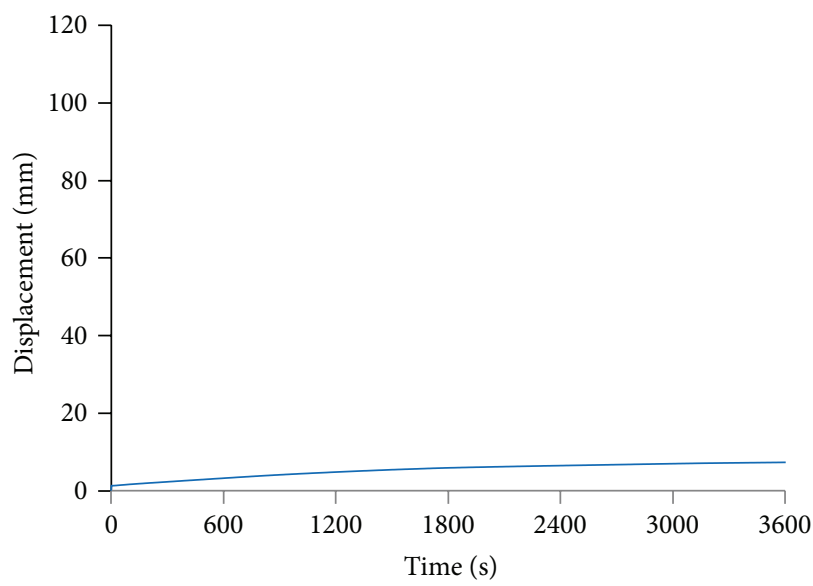

(a) The top point of corner column (longitudinal wind loading)

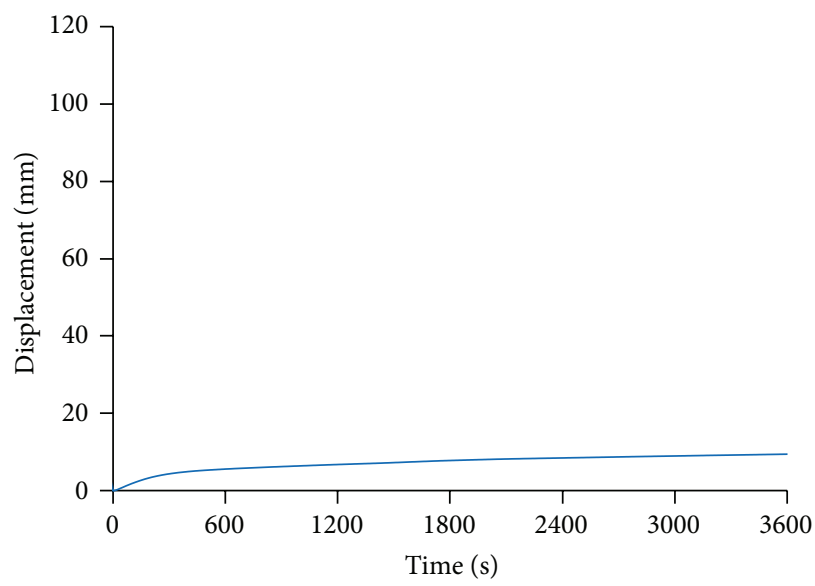

(c) The middle point of bottom side beam (longitudinal wind loading)

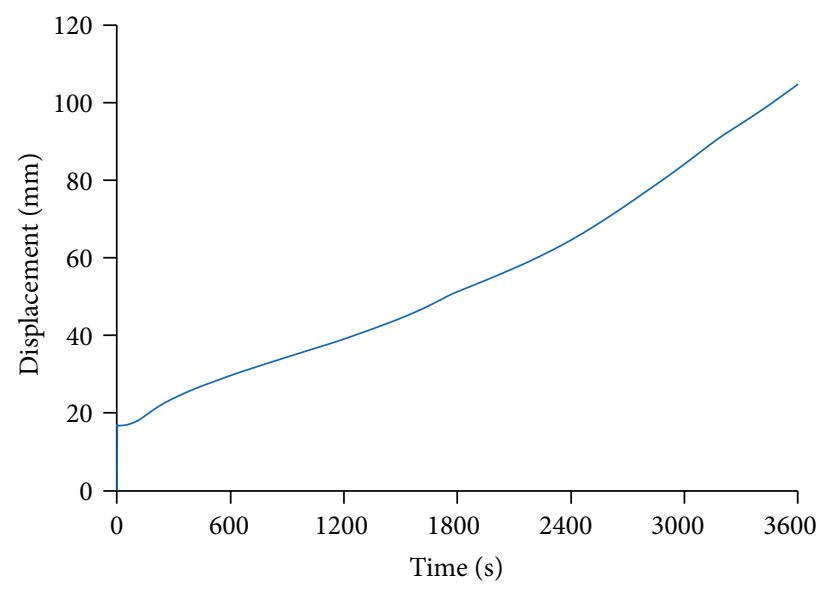

(b) The top point of corner column (lateral wind loading)

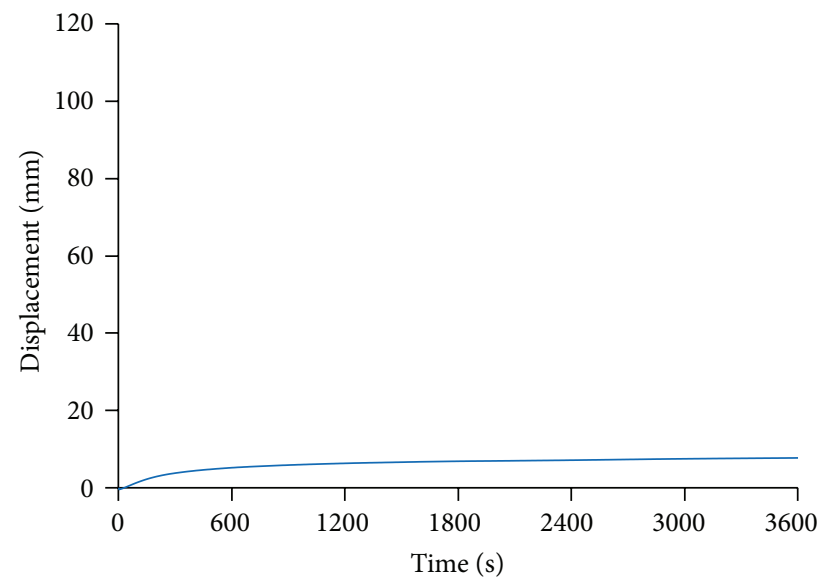

(d) The middle point of bottom side beam (lateral wind loading)

FIGURE 16: The displacement-time curves under the temperature field and external loading.

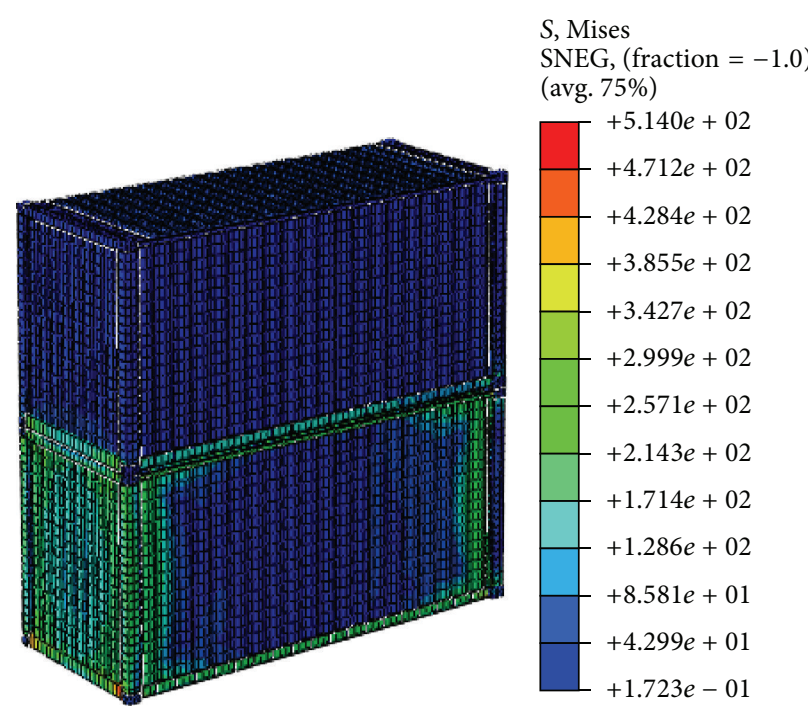

(a) The Mises stress contour under the temperature field and longitudinal wind loading

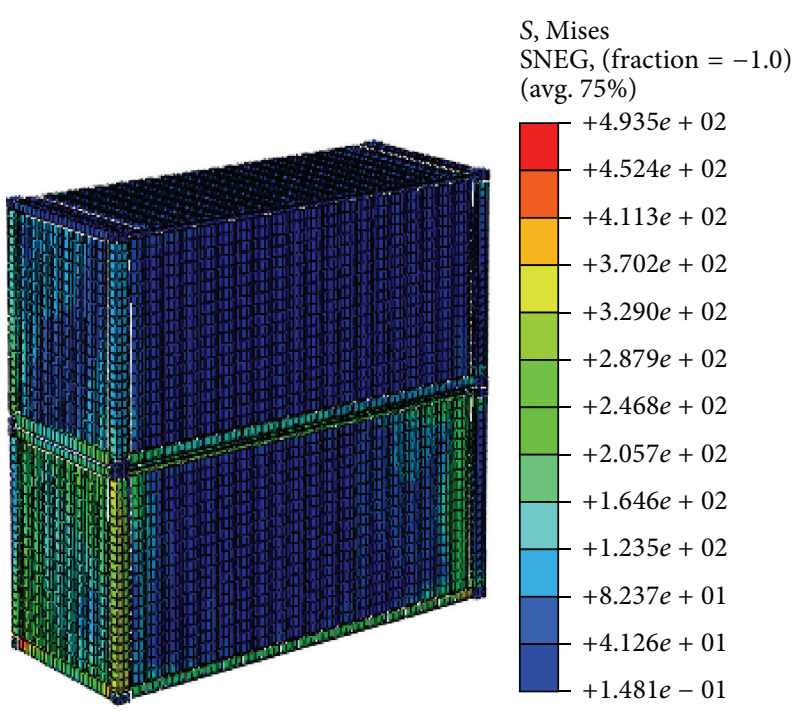

(b) The Mises stress contour under the temperature field and lateral wind loading

Figure 17: The Mises stress contours of the bottom and second layers at $1200 \mathrm{~s}$. 

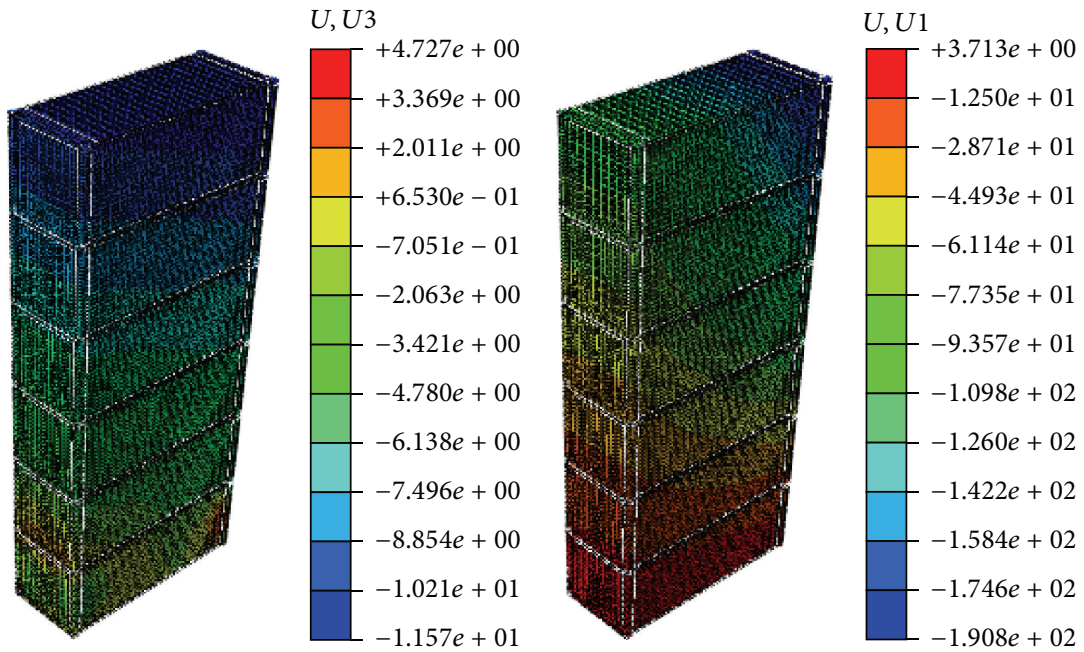

(a) The displacement contour under the temperature field and longitudinal wind loading

(b) The displacement contour under the temperature field and lateral wind loading

FIGURE 18: The displacement contours of the container structure at $1200 \mathrm{~s}$.

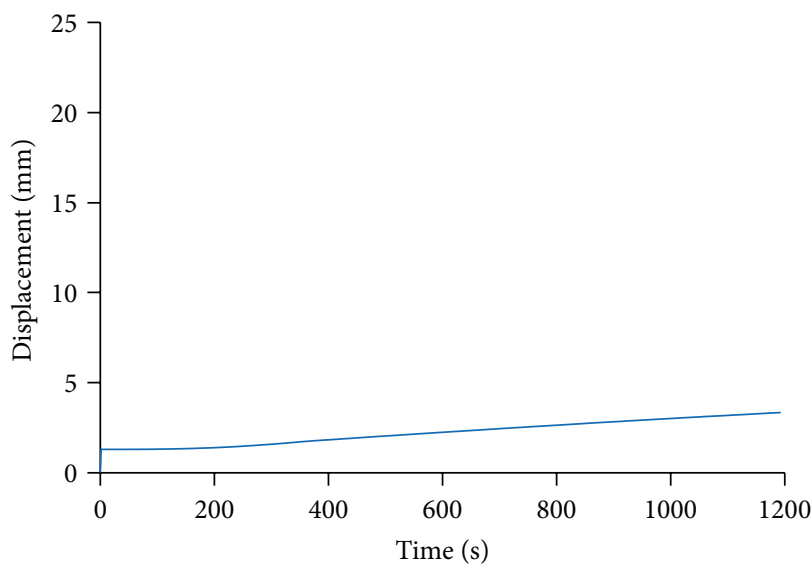

(a) The top point of corner column (longitudinal wind loading)

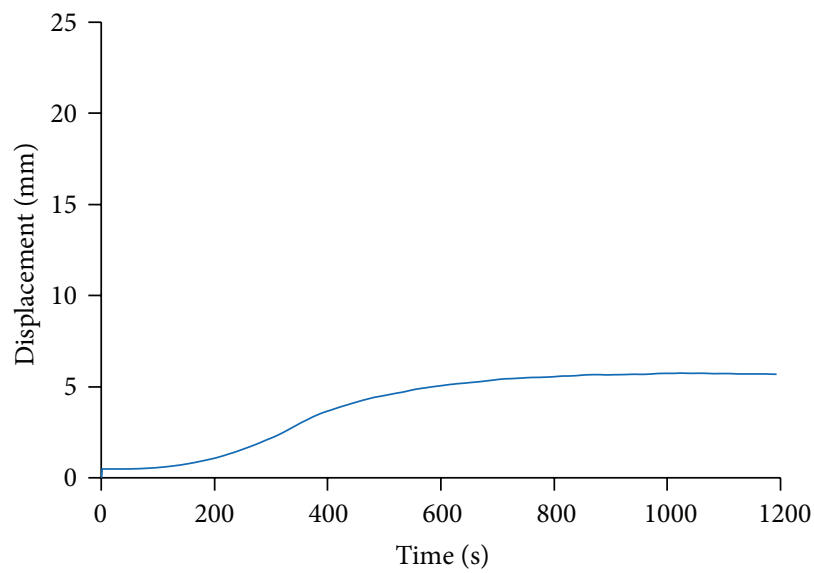

(c) The middle point of bottom side beam (longitudinal wind loading)

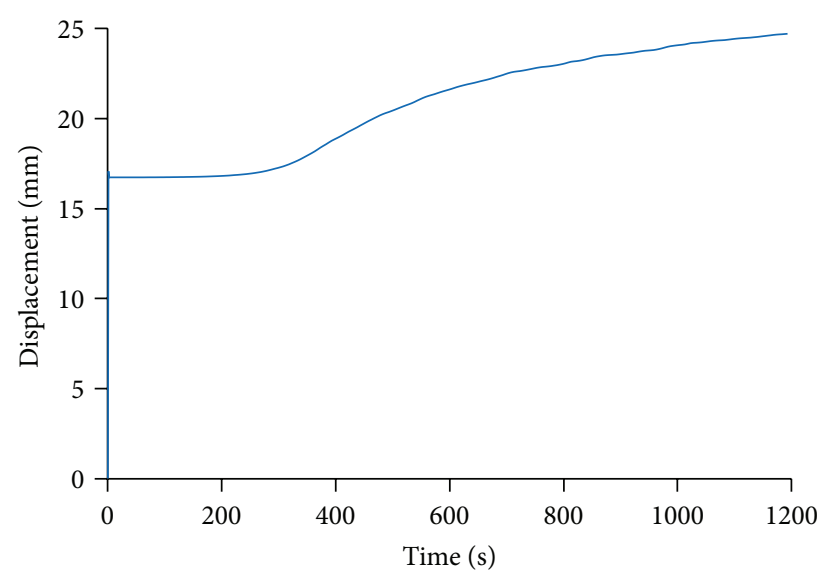

(b) The top point of corner column (lateral wind loading)

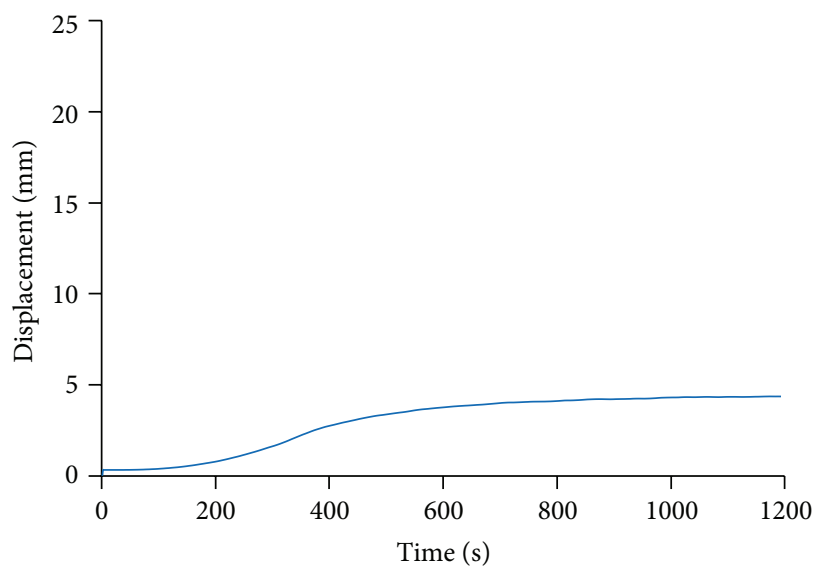

(d) The middle point of bottom side beam (lateral wind loading)

FIGURE 19: The displacement-time curves under the temperature field and external loading. 

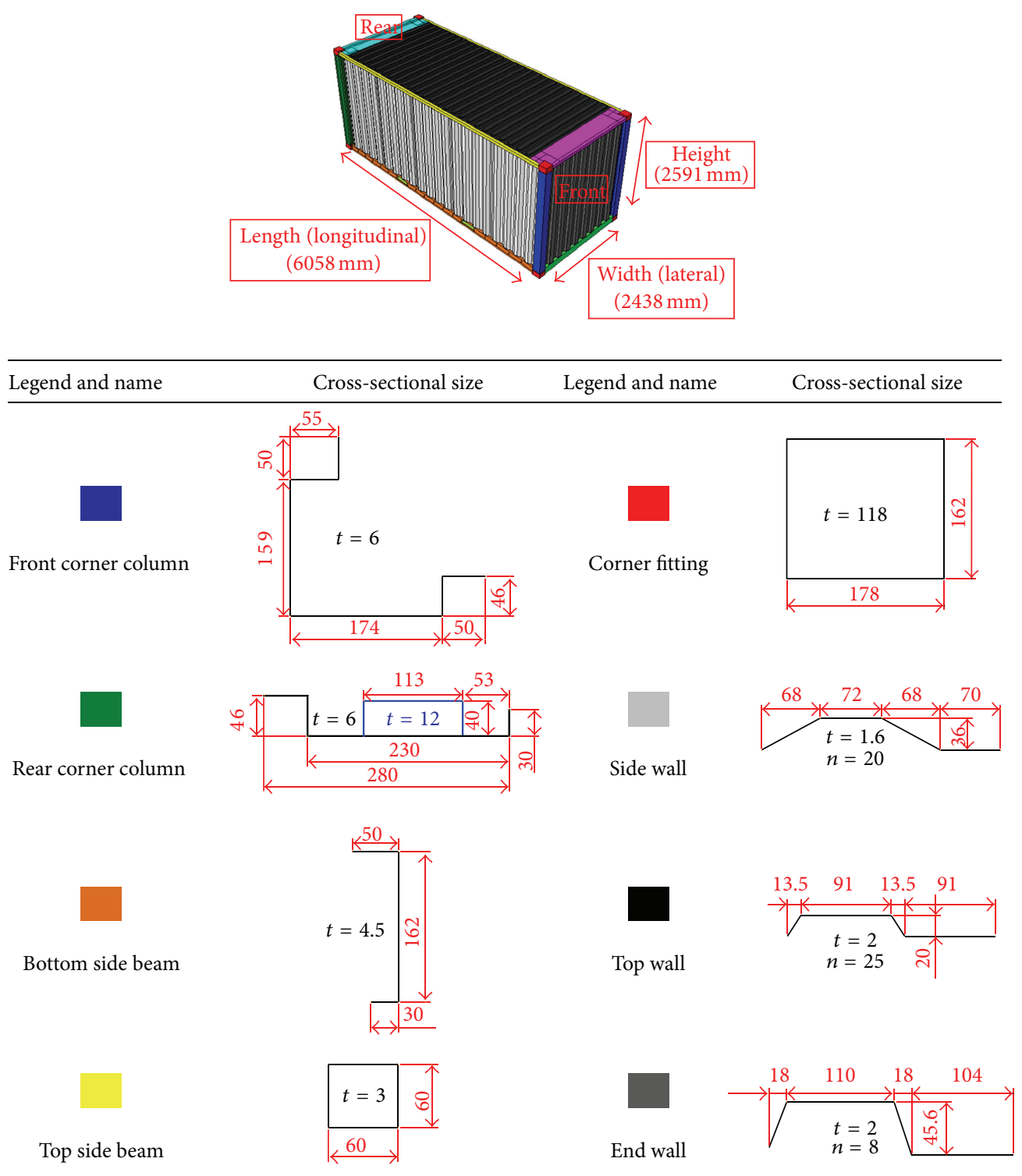

Figure 20: The main container members and size.

that the constraints of the side wall on the bottom side beam decrease with increasing of the time and temperature.

According to the limit condition, when the displacement of corner column reaches $h / 50=52 \mathrm{~mm}$ and the displacement of bottom side beam reaches $l / 250=24.2 \mathrm{~mm}$, the overall structure reaches the limit condition. According to Figure 19, the maximum displacement of corner column is $3.3 \mathrm{~mm}$ and $24.8 \mathrm{~mm}$ under longitudinal and lateral wind loading, respectively, and the maximum displacement of bottom beam is $5.7 \mathrm{~mm}$ and $4.4 \mathrm{~mm}$ under longitudinal and lateral wind loading, respectively.

So, under the actual temperature curve, the container structure can meet the fire resistance requirements on the condition of the bottom side beam and corner column with fire protection only and the side wall without fire protection.

\section{Conclusions}

For the container building structure, prescriptive fire design is too conservative, and performance-based fire design is more reasonable. The performance-based fire design is not only economic but also safe. In this paper, two methods (of the prescriptive fire design and the performance-based fire design) are used in the fire design of the container structure under the temperature field and external loading. The main conclusions are as follows.

(1) Using the software of FDS, the actual temperature curves (of the top and bottom temperature curves of the middle, door, and corner position in the container) have been obtained. Through comparison 
with the standard temperature curve of ISO-834, the importance and necessity of the study on the actual temperature curve can be found and show the science of the study on the performance-based fire design.

(2) Using the software of Abaqus, two temperature fields under the standard temperature curve of ISO-834 and the actual temperature curve (of the most unfavorable curve of the top temperature curve of the middle position in the container) are obtained, respectively. Through comparison with two temperature fields, if the standard temperature curve of ISO-834 (prescriptive fire design) is used, the results will be very conservative and lead to high cost.

(3) Using the method of thermal-mechanical coupled analysis, on the condition of the bottom side beam and corner column with fire protection only, and the side wall without fire protection, the container structure can meet the fire resistance requirements under the actual temperature curve (performance-based fire design), otherwise it cannot meet the fire resistance requirements under the standard temperature curve of ISO-834 (prescriptive fire design).

\section{Notations}

$t$ : The thickness of container members

$n$ : The number of wave of corrugated sheet

E: $\quad$ The elastic modulus of container steel

$\mu: \quad$ The Poisson ratio of container steel

$\rho: \quad$ The density of steel

$\sigma_{s}: \quad$ The yield stress of container steel

$\sigma_{b}: \quad$ The ultimate stress of container steel

$\varepsilon_{s}$ : The yield strain of container steel

$T: \quad$ The temperature

$\lambda_{s}$ : The thermal conduction coefficient of steel

$C_{s}$ : The specific heat of steel

$\alpha_{s}$ : The thermal expansion coefficient of steel

$E_{T}$ : The elastic modulus of steel under $T$ temperature

$\chi_{T}: \quad$ The reduction coefficient of elastic modulus of steel under high temperature

$f_{y T}$ : The yield stress of steel under $T$ temperature

$\eta_{T}$ : The reduction coefficient of yield stress of steel under high temperature

Q: $\quad$ The heating release speed of fire source

$Q_{\max }$ : The maximum heating release speed of fire source

$b$ : The developing coefficient of fire

$t$ : The time

$t_{1}$ : The time to reach $Q_{\max }$

$t_{2}$ : The time of fire duration

$t_{3}$ : The time to extinguish fire

$D^{*}$ : The diameter of equivalent fire source

$\rho_{a}$ : The density of air

$c_{P}$ : The specific heat of air at constant pressure

$g:$ The gravity acceleration

$h$ : The height of steel frame $l$ : The length of steel frame

$\Delta_{h}:$ The column displacement

$\Delta_{l}$ : The beam displacement.

\section{Conflict of Interests}

The authors declare that there is no conflict of interests regarding the publication of this paper.

\section{References}

[1] J. Kotnik, Container Architecture, Leading International Key Services Barcelona, Barcelona, Spain, 2013.

[2] H. Slawik, J. Bergmann, and M. Buchmeier, Container Atlas: A Practical Guide to Container Architecture, Die Gestalten, Berlin, Germany, 2010.

[3] P. Sawyers, Expanded Discussion: Of the Method for Converting Shipping Containers into a Habitable Steel Building, CreateSpace Independent Publishing Platform, North Charleston, SC, USA, 2011.

[4] A. Gordon, B. Bergdoll, W. F. Mclean et al., Quik Build: Adam Kalkin's ABC of Container Architecture, Bibliotheque McLean, London, UK, 2008.

[5] J. D. Smith, Shipping Containers as Building Component, University of Brighton, Brighton, UK, 2005.

[6] V. Aguiar De Souza, L. Kirkayak, K. Suzuki, H. Ando, and H. Sueoka, "Experimental and numerical analysis of container stack dynamics using a scaled model test," Ocean Engineering, vol. 39, pp. 24-42, 2012.

[7] V. Aguiar de Souza, L. Kirkayak, I. Watanabe et al., "Experimental and numerical analysis of container multiple stacks dynamics using a scaled model," Ocean Engineering, vol. 74, pp. 218-232, 2013.

[8] A. D. S. Vinicius, Study on the Dynamic Response of Container Stacks Using Non-Linear Finite Element Analysis, The University of Tokyo, Tokyo, Japan, 2011.

[9] L. Kirkayak, V. A. de Souza, K. Suzuki, H. Ando, and H. Sueoka, "On the vibrational characteristics of a two-tier scaled container stack," Journal of Marine Science and Technology, vol. 16, no. 3, pp. 354-365, 2011.

[10] T. Børvik, A. Burbach, H. Langberg, and M. Langseth, "On the ballistic and blast load response of a $20 \mathrm{ft}$ ISO container protected with aluminium panels filled with a local mass-phase II: validation of protective system," Engineering Structures, vol. 30, no. 6, pp. 1621-1631, 2008.

[11] T. Børvik, A. G. Hanssen, S. Dey, H. Langberg, and M. Langseth, "On the ballistic and blast load response of a $20 \mathrm{ft}$ ISO container protected with aluminium panels filled with a local massphase I: design of protective system," Engineering Structures, vol. 30, no. 6, pp. 1605-1620, 2008.

[12] B. F. Harrison, "Blast resistant modular buildings for the petroleum and chemical processing industries," Journal of Hazardous Materials, vol. 104, no. 1-3, pp. 31-38, 2003.

[13] S. C. Sinha, V. Prakash, P. B. Ravikumar, and R. Raman, "Modeling and simulation of cargo containers," Computers \& Structures, vol. 33, no. 4, pp. 1065-1072, 1989.

[14] K. Giriunas, H. Sezen, and R. B. Dupaix, "Evaluation, modeling, and analysis of shipping container building structures," Engineering Structures, vol. 43, no. 5, pp. 48-57, 2012. 
[15] K. A. Giriunas, Modeling, and Analysis of Shipping Container Building Structures, Ohio State University, Columbus, Ohio, USA, 2012.

[16] X. X. Zha, Y. Zuo, and S. Y. Chen, "Study on the optimal design of the members of contaniner building with building materials I: side board optimization," Advanced Materials Research, vol. 859, pp. 270-273, 2013.

[17] X. X. Zha, Y. Zuo, and S. Y. Chen, "Study on the optimal design of the members of contaniner building with building materials II: joint and corner column optimization," Advanced Materials Research, no. 859, pp. 266-269, 2013.

[18] Y. Zuo and X. X. Zha, "Analysis of longitudinal stiffness of container building structure with holes," Journal of Tianjin University (Science and Technology), no. 2, pp. 167-176, 2015.

[19] X. X. Zha, Y. Zuo, and L. Liu, "Study on theory and finite element analysis of longitudinal stiffness of multi-body container building," Progress in Steel Building Structures, no. 4, pp. 24-28, 2014.

[20] X. X. Zha, Y. Zuo, L. Liu et al., "Analysis of mechanical properties of container structure under earthquake action," Journal of South China University of Technology (Natural Science Edition), no. 7, pp. 92-99, 2015.

[21] L. Liu, Study on the Mechanical Properties of Container Light Steel Structure under Horizontal Load in Normal and High Temperature, Harbin Institute of Technology, Harbin, China, 2013.

[22] X. X. Zha, Calculating Theory of Light Steel Prefabricated House-Static and Dynamic, Optimization, Performance-Based Fire Design, Container Building, Science Press, Beijing, China, 2011.

[23] CEN, "Eurocode 3: design of steel structures-part 1-2: general rules-structural fire design,” EN 1993-1-2:2005, CEN, Brussels, Belgium, 2005.

[24] ISO, ISO/TC 104. ISO 668: 2013. Series 1 Freight ContainersClassification, Dimensions and Ratings, International Organization for Standardization, Geneva, Switzerland, 2013.

[25] China Academy of Building Research, GB 50009-2012. Load Code for the Design of Building Structures, China Architecture \& Building Press, Beijing, China, 2012.

[26] Dassault Systèmes, ABAQUS/CAE User's Manual, Dassault Systèmes, Paris, France, 2014.

[27] Dassault Systèmes, ABAQUS Analysis User's Manual, Dassault Systèmes, Paris, France, 2014.

[28] Z. Zhuang, X. C. You, J. H. Liao et al., Finite Element Analysis and Application Based on ABAQUS, Tsinghua University Press, Beijing, China, 2009.

[29] ISO, ISO/TC 164. ISO 6892-1: 2009. Metallic Materials-Tensile Testing-Part 1: Method of Test at Room Temperature, International Organization for Standardization, Geneva, Switzerland, 2009.

[30] P. J. DiNenno, C. L. Beyler, R. L. P. Custer et al., SFPE Handbook of Fire Protection Engineering, Society of Fire Protection Engineers, Boston, Mass, USA, 1995.

[31] I. R. Thomas and I. D. Bennetts, "Developments in the design of steel structures for fire," Journal of Constructional Steel Research, vol. 23, no. 1, pp. 295-312, 1992. 


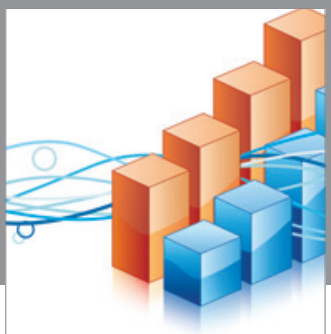

Advances in

Operations Research

vatem alat4

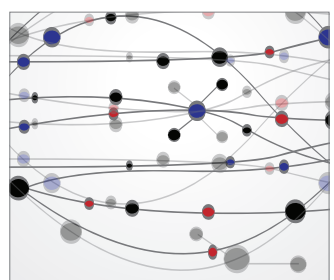

\section{The Scientific} World Journal
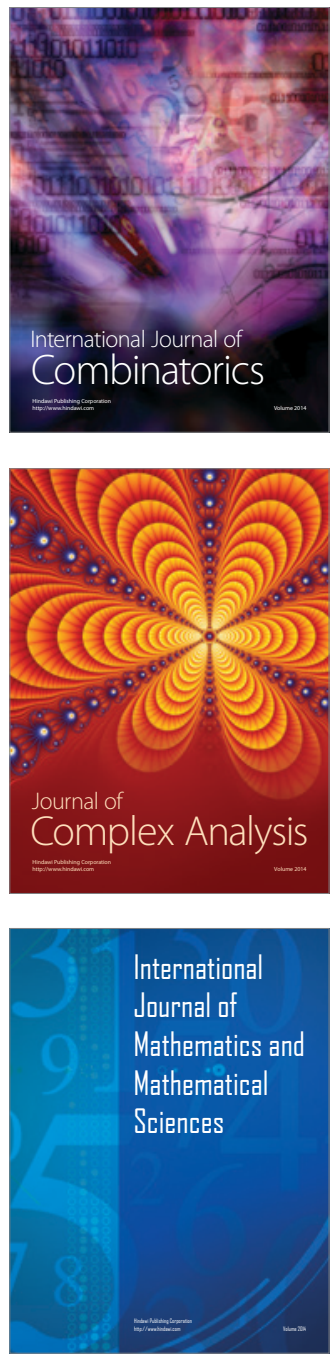
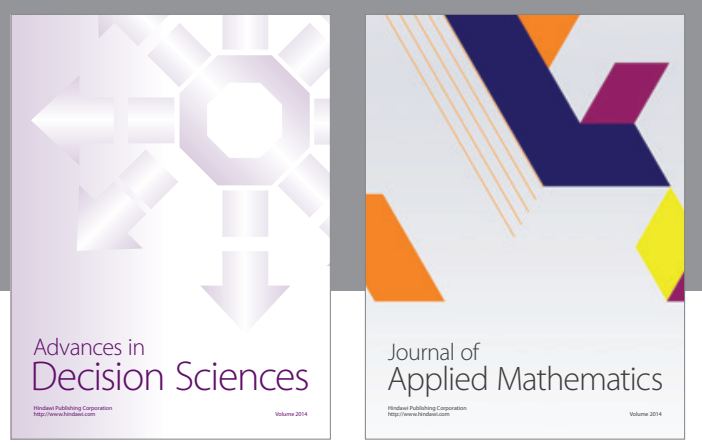

Algebra

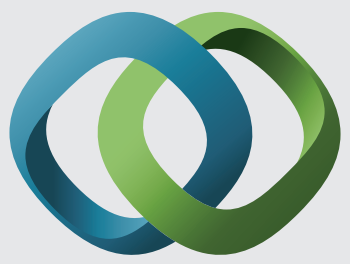

\section{Hindawi}

Submit your manuscripts at

http://www.hindawi.com
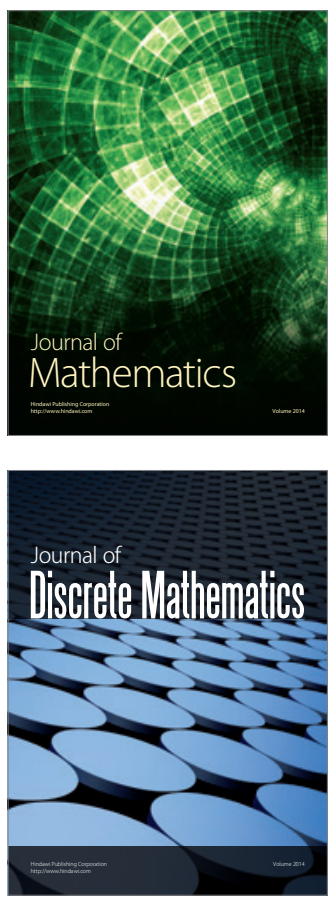

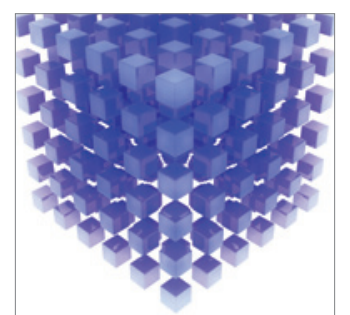

Mathematical Problems in Engineering
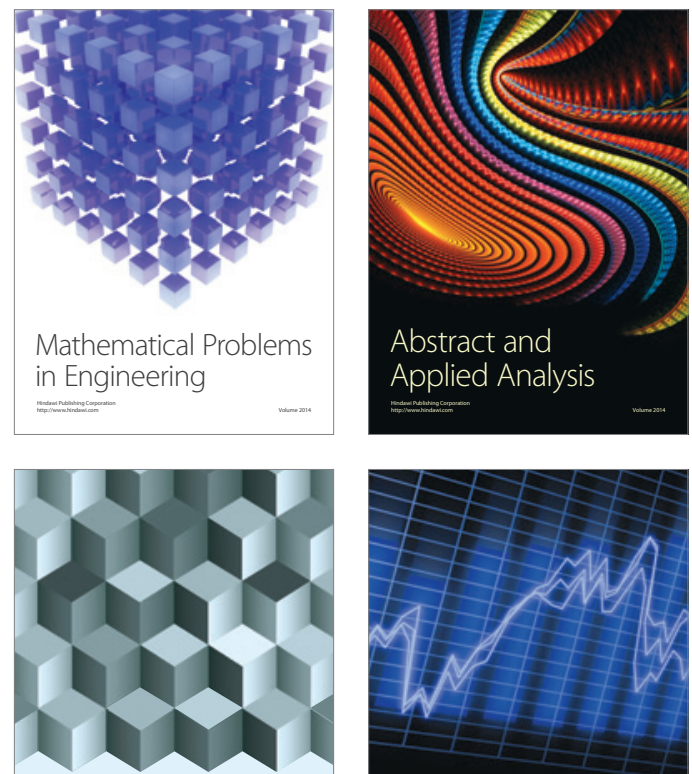

Journal of

Function Spaces

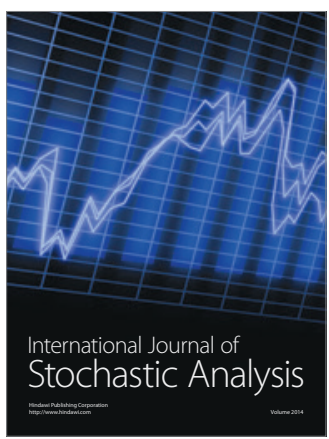

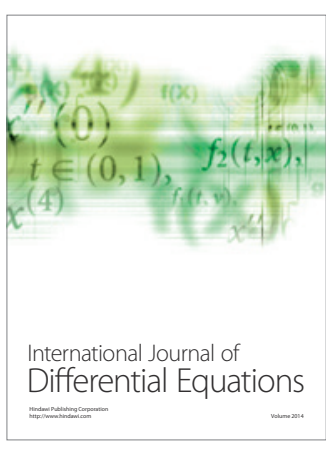
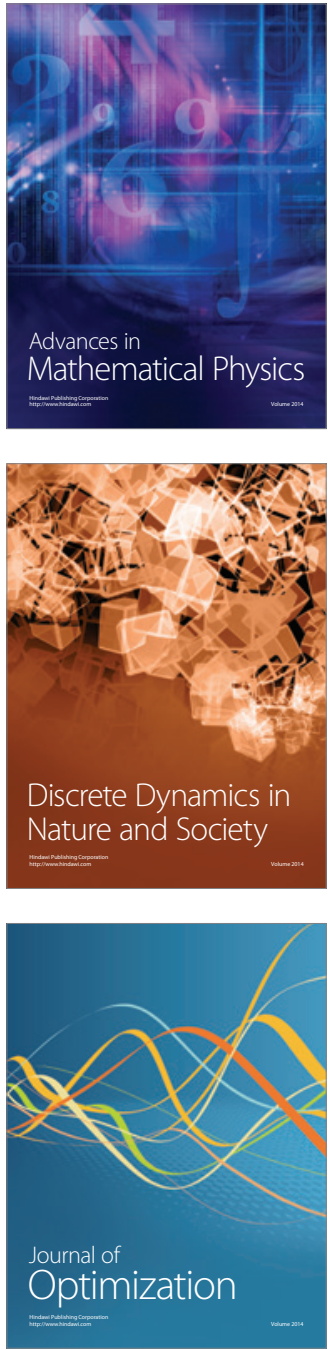